\title{
The Impact of Foreign Direct Investment on Economic Growth: Nigeria Experience
}

\author{
Kolade Omoniyi Alabi \\ Department of Business Administration, Institute of Social Sciences, Istanbul Aydin University, Istanbul, Turkey \\ Email: alabikoladeomoniyi@gmail.com
}

How to cite this paper: Alabi, K.O. (2019) The Impact of Foreign Direct Investment on Economic Growth: Nigeria Experience. Open Journal of Applied Sciences, 9, 372-385. https://doi.org/10.4236/ojapps.2019.95031

Received: April 24, 2019

Accepted: May 24, 2019

Published: May 27, 2019

Copyright $\odot 2019$ by author(s) and Scientific Research Publishing Inc. This work is licensed under the Creative Commons Attribution International License (CC BY 4.0).

http://creativecommons.org/licenses/by/4.0/

\begin{abstract}
This study investigated the impact of foreign direct investment on economic growth in Nigeria. Secondary source of data was employed in this study from 1986 to 2017 which were sourced from Central Bank of Nigeria Statistical Bulletin (2017) published in 2018 and World Development Indicator published in 2019. Descriptive and regression analyses were used as the estimation techniques. The findings of the study revealed that the coefficient value of LFDI is 0.633506 and its p-value is 0.0002 implying that a unit increase in LFDI will increase LGDP with the value of 0.633506 . The coefficient value of RINTR is 0.004127 with p-value of 0.310 indicating that a unit increase in real interest rate will increase gross domestic product, but it is not significant. Also, LDI coefficient value is 1.758036 with p-value of 0.0688 implying that a unit increase in domestic investment will increase gross domestic product positively with the value of 1.758036 which is significant at $10 \%$ but not significant at $5 \%$ alpha level. The coefficient value of exchange rate is 0.835206 with the p-value of 0.0000 signifying that exchange rate is positive and significant to economic growth. It was concluded that foreign direct investment was positive and significant to economic growth of Nigeria while the domestic investment was also positive but not significant at 5\% alpha level.
\end{abstract}

\section{Keywords}

FDI, Economic Growth, Exchange Rate and Domestic Investment

\section{Introduction}

The role of foreign direct investment on economic growth has been hotly debated in the literature. Some studies are of the view that foreign direct investment contributes positively to the growth of the economy [1]-[6], while some are of the view that FDI only contributes small and it is not significant [7] [8]. How- 
ever, the attributes of FDI in any economy of the world cannot be over-emphasized. Foreign direct investment (FDI) refers to an investment made by an investor either corporate bodies or individuals in a country other than the domestic country of origin of the investor in creating business or buying an asset in the country. [5] opined that foreign direct investment is seen as a process of moving technology and capital from a nation either developed or developing countries to another nation. [9] opined that foreign direct investment refers to the package of technology, capital, management, and entrepreneurship that firm uses to operate and provide goods and services in a foreign market. In Africa, Nigeria is the third host economy for FDI, behind Egypt and Ethiopia. Some of the investing countries in Nigeria are the USA, United Kingdom, China, the Netherlands and France [10]. Nigeria FDI flows in 2017 dropped by $21 \%$ to reach 3.5 billion USD which could be as a result of political instability, lack of transparency widespread corruption and poor quality of infrastructure [10]. However, this study tends to re-examine the impact of foreign direct investment on economic growth in $\mathrm{Ni}$ geria.

\section{Literature Review}

[11] examined foreign direct investment and growth on sectors using cross-country data from 1981 to 1999 . The findings showed that total FDI exerts an unclear effect on growth. Foreign direct investments in the primary sector have a negative effect on growth, in the manufacturing a positive was found while in the service sector, the finding is ambiguous. [7] studied the impact of foreign direct investment on economic growth in Nigeria from 1970-2001 using Error Correction Model. The findings revealed that private capital and foreign capital have little effect on the economic growth and it's not statistically significant and financial development showed a significant negative effect on growth based on the findings which could be as a result of high capital flight it generates.

[12] investigated the relationship between foreign direct investment (FDI) and growth from 1980 to 2004 for 58 countries using panel VAR model and GMM analyses. The result of the study revealed that no definite evidence on the growth-effects of FDI and the factors that cause GDP and FDI may be different in relation to the level of income of the country. [8] examined the impact of foreign direct investment on economic growth in Jordan from 1990 to 2009 using co-integration and error correction mechanism. The result shows that foreign direct investment inflows do not exert an independent influence on economic growth.

[2] investigated the impact of foreign direct investment on economic growth using South Korea as a case study from 1980 to 2009. Multiple regression was employed as the estimation technique and the result found that there exist a strong and positive impact of foreign direct investment on economic growth in South Korea during the study period. [3] examined the impact of foreign direct investment (FDI) on Economic Growth in Nigeria from 1986-2007 using mul- 
tiple regression models. From the analysis, it was found that FDI has the potential to positively impact upon the economy though its contribution to GDP was very low within the period under review.

[13] wrote on the causal interactions between FDI, and economic growth: a case study of 65 countries using panel co-integration and Granger causality tests. The results show a unidirectional causality from foreign direct investment to gross domestic product while the panel cointegration revealed a disparity result during the study period. [4] studied impact of foreign direct investment on $\mathrm{Ni}$ geria economic growth from 1999 to 2013 using ordinary least square regression method. The result of the findings showed that inflow of foreign direct investment is positive and statistically significant to economic growth of Nigeria.

[5] wrote on the effect of foreign direct investment on economic growth in Nigeria spans from 1981 to 2015 using multiple regression technique. The study found that foreign direct investment in Nigeria has a positive and significant effect on economic growth proxied with gross domestic product. It was also found that exchange rate has a positive but not significant effect on gross domestic product. [6] studied the impact of foreign direct investment (FDI) on the economic growth of Pakistan from a period of 1991-2015. Correlation and regression analysis techniques analysis were used in the study. Their findings revealed that FDI exists a positive impact on the economic growth of Pakistan.

Conclusively, the empirical review from previous researchers has showed different results using different methodology and time period in the literature both in developed and developing countries of the world. Based on the researcher's knowledge, there exist few studies in Nigeria on foreign direct investment and its impact on economic growth, which inspires the researcher to examine the subject matter.

\section{Methodology}

In order to achieve the broad objective of this study, the model of [5] was adapted. In his study of the effect of foreign direct investment on economic growth in Nigeria, the model was specified as:

$$
\mathrm{GDP}=\mathrm{f}(\mathrm{FDI}, \mathrm{EXR})
$$

where:

$$
\begin{aligned}
& \text { GDP = Gross Domestic Product } \\
& \text { FDI = Foreign Direct Investments } \\
& \text { EXR = Exchange Rate }
\end{aligned}
$$

This study adapted the above model by extending the variables and the time covered. However, this study model is presented as:

$$
\mathrm{RGDP}=\mathrm{f}(\mathrm{FDI}, \mathrm{INT}, \mathrm{REXR}, \mathrm{DI})
$$

where

$$
\begin{aligned}
& \text { GDP }=\text { Gross Domestic Product } \\
& \text { FDI = Foreign Direct Investment } \\
& \text { INT = Interest Rate }
\end{aligned}
$$


REXR = Real Exchange Rate

DI $=$ Domestic Investment

The econometric form of the functional model is specified as:

$$
\mathrm{GDP}=\mu_{0}+\mu_{1} \mathrm{FDI}+\mu_{2} \mathrm{INT}+\mu_{3} \mathrm{REXR}+\mu_{4} \mathrm{DI}+\varepsilon_{t}
$$

where

$\mu_{0}=$ Constant

$\mu_{1}-\mu_{4}=$ Shift Parameters

Time series of the econometric form is presented as:

$$
\mathrm{GDP}_{t}=\mu_{0}+\mu_{1} \mathrm{FDI}_{t}+\mu_{2} \mathrm{INT}_{t}+\mu_{3} \mathrm{REXR}_{t}+\mu_{4} \mathrm{DI}_{t}+\varepsilon_{t}
$$

$t=$ time series

The log-linearity form is used in order to have the same unit of values for the variables and the mathematical form is stated as:

$$
\mathrm{LGDP}_{t}=\mu_{0}+\mu_{1} \mathrm{LFDI}_{t}+\mu_{2} \mathrm{LINT}_{t}+\mu_{3} \mathrm{LREXR}_{t}+\mu_{4} \mathrm{LDI}_{t}+\varepsilon_{t}
$$

$\mathrm{L}=\log$

\section{Result and Discussion}

\subsection{Descriptive Analysis}

Table 1 shows the descriptive result of the variables employed. The result reveals the mean, median, maximum, minimum and standard deviation and the skewness, Kurtosis and Jarque Bera statistics. It reveals that the average value of log of gross domestic product is 12.90291, log of foreign direct investment is 9.313595 , real interest rate is $2.287485, \log$ of domestic investment is 10.72790 while log of exchange rate is 1.727817. The median result shows that LGDP is 12.98819, LFDI is 9.273962, RINTR is 4.997936, LDI is 10.72849 and LEXTR is 2.060034. The maximum, minimum and standard deviation were equally presented in the above table. However, the skewness statistics reveals that all the variables

Table 1. Descriptive result.

\begin{tabular}{cccccc}
\hline & LGDP & LFDI & RINTR & LDI & LEXTR \\
\hline Mean & 12.90291 & 9.313595 & 2.287485 & 10.72790 & 1.727817 \\
Median & 12.98819 & 9.273962 & 4.997936 & 10.72849 & 2.060034 \\
Maximum & 14.06032 & 9.946507 & 18.18000 & 10.84983 & 2.485647 \\
Minimum & 11.29694 & 8.286041 & -31.45257 & 10.57654 & 0.305480 \\
Std. Dev. & 0.880819 & 0.426065 & 10.53346 & 0.070572 & 0.604637 \\
Skewness & -0.365705 & -0.297041 & -1.080016 & -0.146531 & -0.809609 \\
Kurtosis & 1.851657 & 2.413428 & 4.597050 & 2.547906 & 2.401062 \\
Jarque-Bera & 2.471533 & 0.929335 & 9.621740 & 0.387033 & 3.974128 \\
Probability & 0.290612 & 0.628344 & 0.008141 & 0.824056 & 0.137097 \\
Sum & 412.8930 & 298.0350 & 73.19952 & 343.2929 & 55.29015 \\
Sum Sq. Dev. & 24.05110 & 5.627484 & 3439.565 & 0.154392 & 11.33317 \\
Observations & 32 & 32 & 32 & 32 & 32 \\
\hline
\end{tabular}

Source: Eviews 9.0 
such LGDP, LFDI, RINTR, LDI and LEXTR are negatively skewed with the values of $-0.365705,-0.297041,-1.080016,-0.146531$ and -0.809609 respectively. The Kurtosis statistics reveal that LGDP, LFDI, LDI and LEXTR are platykurtic that is, they are less than 3 while RINTR is leptokurtic that is, more than 3 . The Jarque-Bera statistics through its probability reveal that all the variables are normally distributed except RINTR which is not normally distributed during the study period.

\subsection{Unit Root Result}

The unit root results are presented in the appendix. However, the order of integration was presented in Table 2 and the result reveals that LGDP and RINTR are stationary at level while the other variables such as LFDI, LDI and LEXTR are stationary after converting them to first difference. This implies that all the variables used in this study were stationary during the study period.

\subsection{Regression Analysis}

The regression result revealed in Table 3 shows the constant of -13.30987 with

Table 2. Order of integration.

\begin{tabular}{cccccc}
\hline Variable & \multicolumn{2}{c}{ @Level } & \multicolumn{2}{c}{ @First Difference } & Order of Integration \\
\hline & $t$-statistic & P-value & $t$-statistic & P-value & \\
\hline LGDP & -3.281005 & 0.0246 & - & - & $\mathrm{I}(0)$ \\
LFDI & -2.642153 & 0.0957 & -9.856287 & 0.0000 & $\mathrm{I}(1)$ \\
LDI & -1.753739 & 0.3949 & -9.151749 & 0.0000 & $\mathrm{I}(1)$ \\
RINTR & -3.379988 & 0.0196 & - & - & $\mathrm{I}(0)$ \\
LEXTR & -2.621088 & 0.0996 & -5.643297 & 0.0001 & $\mathrm{I}(1)$ \\
\hline
\end{tabular}

Source: Author's computation (2019).

Table 3. Regression result.

\begin{tabular}{ccccc}
\hline \multicolumn{5}{c}{ Dependent Variable: LGDP } \\
\hline Method: Least Squares & & \\
\hline Variable & Coefficient & Std. Error & $t$-Statistic & Prob. \\
\hline C & -13.30987 & 9.737832 & -1.366821 & 0.1830 \\
LFDI & 0.633506 & 0.148892 & 4.254810 & 0.0002 \\
RINTR & 0.004127 & 0.003914 & 1.054527 & 0.3010 \\
LDI & 1.758036 & 0.927383 & 1.895696 & 0.0688 \\
LEXTR & 0.835206 & 0.131672 & 6.343062 & 0.0000 \\
R-squared & 0.950369 & Mean dependent var & 12.90291 \\
Adjusted R-squared & 0.943016 & S.D. dependent var & 0.880819 \\
F-statistic & 129.2529 & Durbin-Watson stat & 1.108331
\end{tabular}

Source: Eviews 9.0. 
p-value of 0.1830 indicating that when all variables such as LFDI, RINTR, LDI and LEXTR are being held constant, there will be negative variation up to the tune of 13.30987 with an insignificant direction. The coefficient value of LFDI is 0.633506 and its p-value is 0.0002 implying that a unit increase in LFDI will increase LGDP with the value of 0.633506 that is, foreign direct investment exhibits a positive and significant impact on economic growth of Nigeria. The coefficient value of RINTR is 0.004127 with p-value of 0.310 indicating that a unit increase in real interest rate will increase gross domestic product but it is not significant that is, RINTR is positive but not significant to economic growth during the study period. Also, LDI coefficient value is 1.758036 with p-value of 0.0688 implying that a unit increase in domestic investment will increase gross domestic product positively with the value of 1.758036 which is significant at $10 \%$ but not significant at $5 \%$ alpha level. The coefficient value of exchange rate is 0.835206 with the p-value of 0.0000 signifying that exchange rate is positive and significant to economic growth.

More so, the coefficient of multiple determinant which is also known as goodness of fit $\left(\mathrm{R}^{2}\right)$ value is 0.950369 and adjusted $\mathrm{R}^{2}$ is 0.943016 . This implies that the independent variables have above $95 \%$ variation in the dependent variable (economic growth). The F-statistic value is 129.2529 and its p-value is 0.0000000 indicating that all the independent variables (LFDI, RINTR, LDI and LEXTR) can jointly influence the dependent variable during the study period.

\section{Conclusion and Recommendations}

This study investigated the impact of foreign direct investment on economic growth in Nigeria from 1986 to 2017. Several reviews were been done based on the existing literature relating to the subject matter. From the findings, this study concluded that foreign direct investment was positive and significant to economic growth of Nigeria while the domestic investment was also positive but not significant at $5 \%$ alpha level. It was equally concluded that real interest rate and exchange rate were both positive, and real interest rate was not significant, but exchange rate was significant to influence economic growth of Nigeria. This study recommended that the government and the policy makers should create more avenues to attract foreign investors which will enhance technology transfer, and more job opportunities, and increase productivity into the economy. It is also recommended that the domestic investors need not to be ignored in formulating policy that could attract and motivate existing and potential domestic investors in Nigeria.

\section{Conflicts of Interest}

The author declares no conflicts of interest regarding the publication of this paper.

\section{References}

[1] Adegbite, E.O. and Ayadi, F.S. (2011) The Role of Foreign Direct Investment in 
Economic Development: A Study of Nigeria. World Journal of Entrepreneurship, Management and Sustainable Development, 6, 133-147. https://doi.org/10.1108/20425961201000011

[2] Koojaroenprasit, B. (2012) The Impact of Foreign Direct Investment on Economic Growth: A Case Study of South Korea. International Journal of Business and Social Science, 3, 8-18.

[3] Onu, J.C. (2012) Impact of Foreign Direct Investment on Economic Growth in Nigeria. Interdisciplinary Journal of Contemporary Research in Business, 4, 64-78.

[4] Adeleke, K.M., Olowe, S.O. and Fasesin, O.O. (2014) Impact of Foreign Direct Investment on Nigeria Economic Growth. International Journal of Academic Research in Business and Social Sciences, 4, 234-242. https://doi.org/10.6007/IJARBSS/v4-i8/1092

[5] John, E.I. (2016) Effect of Foreign Direct Investment on Economic Growth in Nigeria. European Business \& Management, 2, 40-46.

[6] Ali, N. and Hussain, H. (2017) Impact of Foreign Direct Investment on the Economic Growth of Pakistan. American Journal of Economics, 7, 163-170.

[7] Akinlo, A.E. (2004) Foreign Direct Investment and Growth in Nigeria: An Empirical Investigation. Journal of Policy Modeling, 26, 627-639. https://doi.org/10.1016/j.jpolmod.2004.04.011

[8] Louzi, B.M. and Abadi, A. (2011) The Impact of Foreign Direct Investment on Economic Growth in Jordan. IJRRAS, 8, 253-258.

[9] Farrell, R. (2008) Japanese Investment in the World Economy: A Study of Strategic Themes in the Internationalisation of Japanese Industry. Edward Elgar, Britain. https://doi.org/10.4337/9781848442825

[10] UNCTAD (2018) United Nations Conference on Trade and Development. World Investment Report. https://unctad.org/en/PublicationsLibrary/wir2018_en.pdf

[11] Alfaro, L. (2003) Foreign Direct Investment and Growth: Does the Sector Matter? http://www.grips.ac.jp/teacher/oono/hp/docu01/paper14.pdf

[12] Noormamode, S. (2008) Impact of Foreign Direct Investment on Economic Growth: Do Host Country Social and Economic Conditions Matter? 1-39.

[13] Abbes, S.M., Guelli, B.M., Seghir, G.M. and Zakarya, G.Y. (2014) Causal Interactions between FDI, and Economic Growth: Evidence from Dynamic Panel Co-Integration. Procedia Economics and Finance, 3, 276-290.

https://doi.org/10.1016/S2212-5671(15)00541-9 


\section{Appendix}

\section{Data}

\begin{tabular}{|c|c|c|c|c|c|}
\hline Year & LGDP & LFDI & RINTR & LDI & LEXTR \\
\hline 1986 & 11.29694 & 8.28604 & 4.31029 & 10.60448 & 0.30548 \\
\hline 1987 & 11.3886 & 8.78572 & -4.7696 & 10.57654 & 0.604 \\
\hline 1988 & 11.49916 & 8.57826 & -2.9627 & 10.60464 & 0.65674 \\
\hline 1989 & 11.6179 & 9.27514 & -6.6124 & 10.63206 & 0.86874 \\
\hline 1990 & 11.69429 & 8.76929 & 17.4662 & 10.68822 & 0.90514 \\
\hline 1991 & 11.7709 & 8.85271 & 0.99085 & 10.6828 & 0.99605 \\
\hline 1992 & 11.95714 & 8.95262 & -14.987 & 10.68502 & 1.23801 \\
\hline 1993 & 12.0994 & 9.12884 & -7.0525 & 10.71657 & 1.34343 \\
\hline 1994 & 12.24768 & 9.29208 & -15.92 & 10.70576 & 1.34017 \\
\hline 1995 & 12.49139 & 9.03313 & -31.453 & 10.6759 & 1.34017 \\
\hline 1996 & 12.61131 & 9.20234 & -5.2608 & 10.70445 & 1.34017 \\
\hline 1997 & 12.6453 & 9.18736 & 12.1266 & 10.72912 & 1.34017 \\
\hline 1998 & 12.68171 & 9.02174 & 11.4847 & 10.73513 & 1.92328 \\
\hline 1999 & 12.73897 & 9.00213 & 6.04725 & 10.7466 & 1.9654 \\
\hline 2000 & 12.84897 & 9.05697 & -1.1409 & 10.77714 & 2.00347 \\
\hline 2001 & 12.91564 & 9.07577 & 12.1387 & 10.6594 & 2.04932 \\
\hline 2002 & 13.06075 & 9.27279 & 3.02354 & 10.70155 & 2.08271 \\
\hline 2003 & 13.13216 & 9.30219 & 9.93571 & 10.7858 & 2.11204 \\
\hline 2004 & 13.25826 & 9.27278 & -2.6048 & 10.68924 & 2.12548 \\
\hline 2005 & 13.36402 & 9.69745 & -1.5937 & 10.69929 & 2.11939 \\
\hline 2006 & 13.48252 & 9.68613 & -5.628 & 10.84662 & 2.10511 \\
\hline 2007 & 13.54003 & 9.78075 & 9.18717 & 10.7393 & 2.09556 \\
\hline 2008 & 13.60156 & 9.91358 & 6.68491 & 10.72786 & 2.07075 \\
\hline 2009 & 13.6381 & 9.93221 & 18.18 & 10.76895 & 2.16849 \\
\hline 2010 & 13.73729 & 9.78005 & 1.06774 & 10.78603 & 2.17264 \\
\hline 2011 & 13.80027 & 9.94651 & 5.68558 & 10.74866 & 2.18278 \\
\hline 2012 & 13.85945 & 9.84942 & 6.22481 & 10.7596 & 2.19296 \\
\hline 2013 & 13.90854 & 9.7453 & 11.2016 & 10.79248 & 2.19244 \\
\hline 2014 & 13.9549 & 9.66759 & 11.3562 & 10.84719 & 2.19585 \\
\hline 2015 & 13.97854 & 9.49656 & 13.5962 & 10.84983 & 2.28398 \\
\hline 2016 & 14.01104 & 9.64788 & 6.68623 & 10.81988 & 2.48459 \\
\hline 2017 & 14.06032 & 9.54372 & 5.79057 & 10.80675 & 2.48565 \\
\hline
\end{tabular}

Source: WDI 2019 \& CBN 2017

\section{Unit Root Result}




\section{GDP@Level}

Null Hypothesis: LGDP has a unit root

Exogenous: Constant

Lag Length: 0 (Automatic-based on SIC, maxlag = 7)

\begin{tabular}{cccc}
\hline & & $t$-Statistic & Prob. $^{*}$ \\
\hline Augmented Dickey-Fuller test statistic & -3.281005 & 0.0246 \\
Test critical values: & $1 \%$ level & -3.661661 & \\
& $5 \%$ level & -2.960411 & \\
& $10 \%$ level & -2.619160 & \\
\end{tabular}

*MacKinnon (1996) one-sided p-values.

Augmented Dickey-Fuller Test Equation

Dependent Variable: D (LGDP)

Method: Least Squares

Date: 04/17/19 Time: 10:55

Sample (adjusted): 19872017

Included observations: 31 after adjustments

\begin{tabular}{ccccc}
\hline Variable & Coefficient & Std. Error & $t$-Statistic & Prob. \\
\hline LGDP(-1) & -0.029871 & 0.009104 & -3.281005 & 0.0027 \\
C & 0.473449 & 0.117389 & 4.033146 & 0.0004 \\
R-squared & 0.270715 & Mean dependent var & 0.089141 \\
Adjusted R-squared & 0.245568 & S.D. dependent var & 0.049905 \\
S.E. of regression & 0.043346 & Akaike info criterion & -3.376850 \\
Sum squared resid & 0.054488 & Schwarz criterion & -3.284335 \\
Log likelihood & 54.34118 & Hannan-Quinn criter. & -3.346693 \\
F-statistic & 10.76499 & Durbin-Watson stat & 1.406351 \\
Prob (F-statistic) & 0.002696 & & \\
\hline
\end{tabular}

\section{LFDI @ Level}

Null Hypothesis: LFDI has a unit root

Exogenous: Constant

Lag Length: 0 (Automatic-based on SIC, maxlag $=7$ )

\begin{tabular}{|c|c|c|c|}
\hline & & $t$-Statistic & Prob.* \\
\hline \multicolumn{2}{|c|}{ Augmented Dickey-Fuller test statistic } & -2.642153 & 0.0957 \\
\hline \multirow[t]{3}{*}{ Test critical values: } & $1 \%$ level & -3.661661 & \\
\hline & $5 \%$ level & -2.960411 & \\
\hline & $10 \%$ level & -2.619160 & \\
\hline
\end{tabular}

*MacKinnon (1996) one-sided p-values. 


\begin{tabular}{|c|c|c|c|c|}
\hline \multicolumn{5}{|c|}{ Augmented Dickey-Fuller Test Equation } \\
\hline \multicolumn{5}{|c|}{ Dependent Variable: D (LFDI) } \\
\hline \multicolumn{5}{|l|}{ Method: Least Squares } \\
\hline \multicolumn{5}{|l|}{ Date: 04/17/19 Time: $10: 56$} \\
\hline \multicolumn{5}{|c|}{ Sample (adjusted): 19872017} \\
\hline \multicolumn{5}{|c|}{ Included observations: 31 after adjustments } \\
\hline Variable & Coefficient & Std. Error & $t$-Statistic & Prob. \\
\hline $\operatorname{LFDI}(-1)$ & -0.234024 & 0.088573 & -2.642153 & 0.0131 \\
\hline $\mathrm{C}$ & 2.218434 & 0.825131 & 2.688584 & 0.0118 \\
\hline R-squared & 0.194018 & \multicolumn{2}{|c|}{ Mean dependent var } & 0.040570 \\
\hline Adjusted R-squared & 0.166226 & \multicolumn{2}{|c|}{ S.D. dependent var } & 0.228989 \\
\hline S.E. of regression & 0.209093 & \multicolumn{2}{|c|}{ Akaike info criterion } & -0.229737 \\
\hline Sum squared resid & 1.267873 & \multicolumn{2}{|c|}{ Schwarz criterion } & -0.137222 \\
\hline Log likelihood & 5.560921 & \multicolumn{2}{|c|}{ Hannan-Quinn criter. } & -0.199579 \\
\hline F-statistic & 6.980974 & \multirow{2}{*}{\multicolumn{2}{|c|}{ Durbin-Watson stat }} & 2.700983 \\
\hline Prob (F-statistic) & 0.013140 & & & \\
\hline
\end{tabular}

\section{LFDI @ First Difference}

\begin{tabular}{|c|c|c|c|}
\hline \multicolumn{4}{|l|}{ Exogenous: Constant } \\
\hline \multicolumn{4}{|c|}{ Lag Length: 0 (Automatic-based on SIC, maxlag $=7$ ) } \\
\hline & & $t$-Statistic & Prob.* \\
\hline Augmented & Fuller test statistic & -9.856287 & 0.0000 \\
\hline \multirow[t]{3}{*}{ Test critical values: } & $1 \%$ level & -3.670170 & \\
\hline & $5 \%$ level & -2.963972 & \\
\hline & $10 \%$ level & -2.621007 & \\
\hline
\end{tabular}

*MacKinnon (1996) one-sided p-values.

Augmented Dickey-Fuller Test Equation

Dependent Variable: D (LFDI, 2)

Method: Least Squares

Date: 04/17/19 Time: 10:57

Sample (adjusted): 19882017

Included observations: 30 after adjustments

\begin{tabular}{ccccc}
\hline Variable & Coefficient & Std. Error & $t$-Statistic & Prob. \\
\hline D (LFDI $(-1))$ & -1.486495 & 0.150817 & -9.856287 & 0.0000 \\
C & 0.047351 & 0.034974 & 1.353905 & 0.1866 \\
R-squared & 0.776262 & Mean dependent var & -0.020128 \\
\hline
\end{tabular}




\section{Continued}

\begin{tabular}{cccc}
\hline Adjusted R-squared & 0.768271 & S.D. dependent var & 0.390236 \\
S.E. of regression & 0.187853 & Akaike info criterion & -0.441978 \\
Sum squared resid & 0.988080 & Schwarz criterion & -0.348565 \\
Log likelihood & 8.629675 & Hannan-Quinn criter. & -0.412095 \\
F-statistic & 97.14639 & Durbin-Watson stat & 1.873769 \\
Prob (F-statistic) & 0.000000 & & \\
\hline
\end{tabular}

\section{LDI@ Level}

Null Hypothesis: LDI has a unit root

Exogenous: Constant

Lag Length: 2 (Automatic-based on SIC, maxlag $=7$ )

\begin{tabular}{lccc}
\hline & & $t$-Statistic & Prob. $^{*}$ \\
\hline Augmented Dickey-Fuller test statistic & -1.753739 & 0.3949 \\
Test critical values: & $1 \%$ level & -3.679322 & \\
& $5 \%$ level & -2.967767 & \\
& $10 \%$ level & -2.622989 & \\
\hline
\end{tabular}

${ }^{*}$ MacKinnon (1996) one-sided p-values.

Augmented Dickey-Fuller Test Equation

Dependent Variable: D(LDI)

Method: Least Squares

Date: 04/17/19 Time: 10:57

Sample (adjusted): 19892017

Included observations: 29 after adjustments

\begin{tabular}{ccccc}
\hline Variable & Coefficient & Std. Error & $t$-Statistic & Prob. \\
\hline LDI(-1) & -0.228373 & 0.130220 & -1.753739 & 0.0917 \\
D (LDI(-1)) & -0.401444 & 0.156966 & -2.557532 & 0.0170 \\
D (LDI(-2)) & -0.589516 & 0.149331 & -3.947715 & 0.0006 \\
C & 2.466826 & 1.396926 & 1.765896 & 0.0896 \\
R-squared & 0.550800 & Mean dependent var & 0.006969 \\
Adjusted R-squared & 0.496896 & S.D. dependent var & 0.053861 \\
S.E. of regression & 0.038203 & Akaike info criterion & -3.564343 \\
Sum squared resid & 0.036487 & Schwarz criterion & -3.375751 \\
Log likelihood & 55.68297 & Hannan-Quinn criter. & -3.505278 \\
F-statistic & 10.21817 & Durbin-Watson stat & 1.974045 \\
Prob (F-statistic) & 0.000142 & &
\end{tabular}

\section{LDI @ First Difference}




\begin{tabular}{|c|c|c|c|c|}
\hline \multicolumn{5}{|c|}{ Null Hypothesis: D(LDI) has a unit root } \\
\hline \multicolumn{5}{|l|}{ Exogenous: Constant } \\
\hline \multicolumn{5}{|c|}{ Lag Length: 1 (Automatic-based on SIC, maxlag = 7) } \\
\hline & & \multicolumn{2}{|r|}{$t$-Statistic } & Prob. $^{*}$ \\
\hline \multicolumn{3}{|c|}{ Augmented Dickey-Fuller test statistic } & -9.151749 & 0.0000 \\
\hline \multirow[t]{3}{*}{ Test critical values: } & $1 \%$ level & & -3.679322 & \\
\hline & $5 \%$ level & & -2.967767 & \\
\hline & $10 \%$ level & & -2.622989 & \\
\hline \multicolumn{5}{|c|}{ *MacKinnon (1996) one-sided p-values. } \\
\hline \multicolumn{5}{|c|}{ Augmented Dickey-Fuller Test Equation } \\
\hline \multicolumn{5}{|c|}{ Dependent Variable: D (LDI, 2) } \\
\hline \multicolumn{5}{|l|}{ Method: Least Squares } \\
\hline \multicolumn{5}{|l|}{ Date: $04 / 17 / 19$ Time: $10: 58$} \\
\hline \multicolumn{5}{|c|}{ Sample (adjusted): 19892017} \\
\hline \multicolumn{5}{|c|}{ Included observations: 29 after adjustments } \\
\hline Variable & Coefficient & Std. Error & $t$-Statistic & Prob. \\
\hline $\mathrm{D}(\mathrm{LDI}(-1))$ & -2.191882 & 0.239504 & -9.151749 & 0.0000 \\
\hline $\mathrm{D}(\mathrm{LDI}(-1), 2)$ & 0.671792 & 0.147320 & 4.560084 & 0.0001 \\
\hline $\mathrm{C}$ & 0.017017 & 0.007643 & 2.226443 & 0.0349 \\
\hline R-squared & 0.806469 & \multicolumn{2}{|c|}{ Mean dependent var } & -0.001422 \\
\hline Adjusted R-squared & 0.791582 & \multicolumn{2}{|c|}{ S.D. dependent var } & 0.086959 \\
\hline S.E. of regression & 0.039699 & \multicolumn{2}{|c|}{ Akaike info criterion } & -3.517284 \\
\hline Sum squared resid & 0.040976 & \multicolumn{2}{|c|}{ Schwarz criterion } & -3.375839 \\
\hline Log likelihood & 54.00061 & \multicolumn{2}{|c|}{ Hannan-Quinn criter. } & -3.472985 \\
\hline F-statistic & 54.17285 & \multirow{2}{*}{\multicolumn{2}{|c|}{ Durbin-Watson stat }} & 1.958519 \\
\hline Prob (F-statistic) & 0.000000 & & & \\
\hline
\end{tabular}

\section{RINTR@ @evel}

\begin{tabular}{|c|c|c|c|}
\hline \multicolumn{4}{|c|}{ Null Hypothesis: RINTR has a unit root } \\
\hline \multicolumn{4}{|l|}{ Exogenous: Constant } \\
\hline \multicolumn{4}{|c|}{ Lag Length: $0($ Automatic-based on SIC, maxlag $=7)$} \\
\hline & & $t$-Statistic & Prob.* \\
\hline Augmented & Fuller test statistic & -3.379988 & 0.0196 \\
\hline \multirow[t]{3}{*}{ Test critical values: } & $1 \%$ level & -3.661661 & \\
\hline & $5 \%$ level & -2.960411 & \\
\hline & $10 \%$ level & -2.619160 & \\
\hline
\end{tabular}

${ }^{\star}$ MacKinnon (1996) one-sided p-values. 


\begin{tabular}{|c|c|c|c|c|}
\hline \multicolumn{5}{|c|}{ Dependent Variable: D (RINTR) } \\
\hline \multicolumn{5}{|l|}{ Method: Least Squares } \\
\hline \multicolumn{5}{|l|}{ Date: 04/17/19 Time: 10:58 } \\
\hline \multicolumn{5}{|c|}{ Sample (adjusted): 19872017} \\
\hline \multicolumn{5}{|c|}{ Included observations: 31 after adjustments } \\
\hline Variable & Coefficient & Std. Error & $t$-Statistic & Prob. \\
\hline $\operatorname{RINTR}(-1)$ & -0.566449 & 0.167589 & -3.379988 & 0.0021 \\
\hline $\mathrm{C}$ & 1.279485 & 1.799329 & 0.711090 & 0.4827 \\
\hline R-squared & 0.282610 & \multicolumn{2}{|c|}{ Mean dependent var } & 0.047751 \\
\hline Adjusted R-squared & 0.257872 & \multicolumn{2}{|c|}{ S.D. dependent var } & 11.38826 \\
\hline S.E. of regression & 9.810622 & \multicolumn{2}{|c|}{ Akaike info criterion } & 7.467149 \\
\hline Sum squared resid & 2791.201 & \multicolumn{2}{|c|}{ Schwarz criterion } & 7.559665 \\
\hline Log likelihood & -113.7408 & \multicolumn{2}{|c|}{ Hannan-Quinn criter. } & 7.497307 \\
\hline F-statistic & 11.42432 & \multirow{2}{*}{\multicolumn{2}{|c|}{ Durbin-Watson stat }} & 1.940476 \\
\hline Prob (F-statistic) & 0.002086 & & & \\
\hline
\end{tabular}

\section{LEXTR@Level}

\begin{tabular}{|c|c|c|c|}
\hline \multicolumn{4}{|c|}{ Null Hypothesis: LEXTR has a unit root } \\
\hline \multicolumn{4}{|l|}{ Exogenous: Constant } \\
\hline \multicolumn{4}{|c|}{ Lag Length: 0 (Automatic-based on SIC, maxlag $=7$ ) } \\
\hline & & $t$-Statistic & Prob. ${ }^{*}$ \\
\hline Augmented & Fuller test statistic & -2.621088 & 0.0996 \\
\hline \multirow[t]{3}{*}{ Test critical values: } & $1 \%$ level & -3.661661 & \\
\hline & $5 \%$ level & -2.960411 & \\
\hline & $10 \%$ level & -2.619160 & \\
\hline
\end{tabular}

*MacKinnon (1996) one-sided p-values.

Augmented Dickey-Fuller Test Equation

Dependent Variable: D (LEXTR)

Method: Least Squares

Date: 04/17/19 Time: 10:59

Sample (adjusted): 19872017

Included observations: 31 after adjustments

\begin{tabular}{ccccc}
\hline Variable & Coefficient & Std. Error & $t$-Statistic & Prob. \\
\hline LEXTR $(-1)$ & -0.091454 & 0.034892 & -2.621088 & 0.0138 \\
C & 0.226108 & 0.062882 & 3.595768 & 0.0012 \\
R-squared & 0.191527 & Mean dependent var & 0.070328 \\
Adjusted R-squared & 0.163649 & S.D. dependent var & 0.125036 \\
\hline
\end{tabular}




\section{Continued}

\begin{tabular}{cccc}
\hline S.E. of regression & 0.114348 & Akaike info criterion & -1.436799 \\
Sum squared resid & 0.379189 & Schwarz criterion & -1.344283 \\
Log likelihood & 24.27038 & Hannan-Quinn criter. & -1.406641 \\
F-statistic & 6.870103 & Durbin-Watson stat & 2.125516 \\
Prob (F-statistic) & 0.013811 & & \\
\hline
\end{tabular}

\section{LEXTR@ $@$ First Difference}

\begin{tabular}{|c|c|c|c|}
\hline \multicolumn{4}{|c|}{ Null Hypothesis: D(LEXTR) has a unit root } \\
\hline \multicolumn{4}{|l|}{ Exogenous: Constant } \\
\hline \multicolumn{4}{|c|}{ Lag Length: $0($ Automatic-based on SIC, maxlag $=7)$} \\
\hline & & $t$-Statistic & Prob.* \\
\hline \multicolumn{2}{|c|}{ Augmented Dickey-Fuller test statistic } & -5.643297 & 0.0001 \\
\hline \multirow[t]{3}{*}{ Test critical values: } & $1 \%$ level & -3.670170 & \\
\hline & $5 \%$ level & -2.963972 & \\
\hline & $10 \%$ level & -2.621007 & \\
\hline
\end{tabular}

${ }^{\star}$ MacKinnon (1996) one-sided p-values.

Augmented Dickey-Fuller Test Equation

Dependent Variable: D (LEXTR, 2)

Method: Least Squares

Date: 04/17/19 Time: 10:59

Sample (adjusted): 19882017

Included observations: 30 after adjustments

\begin{tabular}{ccccc}
\hline Variable & Coefficient & Std. Error & $t$-Statistic & Prob. \\
\hline D (LEXTR(-1)) & -1.008749 & 0.178752 & -5.643297 & 0.0000 \\
C & 0.063357 & 0.025746 & 2.460879 & 0.0203 \\
R-squared & 0.532139 & Mean dependent var & -0.009916 \\
Adjusted R-squared & 0.515429 & S.D. dependent var & 0.174928 \\
S.E. of regression & 0.121769 & Akaike info criterion & -1.309039 \\
Sum squared resid & 0.415177 & Schwarz criterion & -1.215625 \\
Log likelihood & 21.63558 & Hannan-Quinn criter. & -1.279155 \\
F-statistic & 31.84680 & Durbin-Watson stat & 1.981700 \\
Prob (F-statistic) & 0.000005 & & \\
\hline
\end{tabular}

